\title{
In vitro Nutrient Digestibility and Fermentation Pattern of Concentrate Mixtures Containing Incremental Levels of Dried Distillers Grains with Solubles
}

\author{
R.N. Chandrika, Jasmine Kaur*, J.S. Lamba and R.S. Grewal \\ Department of Animal Nutrition, Guru Angad Dev Veterinary and Animal Sciences \\ University, Ludhiana-141004, India \\ *Corresponding author
}

\section{Keywords}

Buffalo inoculum, Dried distillers grains with solubles, In vitro digestibility, Hydrogen balance, Methane

Article Info

Accepted: 15 June 2018 Available Online: 10 July 2018

\section{A B S T R A C T}

The main objective of the present study was to investigate the effect of incorporation of graded levels of RDDGS in the concentrate mixtures on in vitro nutrient digestibility and rumen fermentation pattern using buffalo inoculum. Soybean meal (SBM) based conventional concentrate mixture was prepared and SBM in the concentrate mixture was replaced by RDDG at graded levels of 25, 50, 75 and 100 per cent on $\mathrm{N}$ basis. The nutritional worth of various concentrate mixtures was assessed by in vitro gas production technique. The in vitro study of concentrates containing graded levels of RDDGS revealed that $\mathrm{OM}, \mathrm{NDF}$ and $\mathrm{DM}$ digestibility increased $(\mathrm{P}<0.05)$ with the increasing level of RDDGS in the concentrate mixture. The MMP of concentrate mixtures increased $(\mathrm{P}>0.05)$ with increasing levels of RDDGS replacing soybean meal. However, the increase in MMP was statistically non-significant. The ME availability was highest $(\mathrm{P}<0.05)$ in concentrate mixtures containing 50 and $75 \%$ RDDGS replacing soybean meal. The ammonical-N of the concentrate mixtures decreased $(\mathrm{P}<0.05)$ with the increase in the inclusion of graded levels of RDDGS in concentrate mixtures replacing SBM. The acetic acid content and A:P $(\mathrm{mM} / \mathrm{dl})$ ratio decreased $(\mathrm{P}<0.05)$ with increasing level of RDDGS replacing SBM in the concentrate mixtures. The inclusion of graded levels of RDDGS in the concentrate mixture was observed to have no significant effect on the methane production in concentrate mixtures. Hence, it was concluded that RDDGS could be considered as promising protein supplement for livestock and can replace conventional oilseed cakes viz., soybean meal upto $75 \%$ in the concentrate mixture without any adverse effect on nutrient digestibility, ME availability, fermentation efficiency and methane production.

\section{Introduction}

In developing countries like India, livestock and dairy plays an important role in the economy and livelihood of people. Livestock contributes $25.6 \%$ of total value of output in agriculture which is $4.11 \%$ of total GDP (National livestock census, 2012). In India, due to its tropical climatic conditions, urbanization, water scarcity, industrialization and non-availability of cultivable land, the gap between availability and requirement of 
nutrients and feedstuffs is increasing. Around $60-70 \%$ of the cost of production is involved in feeding of animals. The cost of conventional feed resources used for feeding livestock has increased because of increased needs of grains by the human population.

Dried distillers grains solubles (DDGS) is an agro-industrial by-product obtained as a coproduct in the production of bio-ethanol from various grains like maize, sorghum, wheat, rice and barley etc. Rice dried distillers grains solubles (RDDGS) is the major co-product from alcohol and rice wine production using broken rice in Asian countries. Very less information is available on the use of RDDGS as a substitute of costly conventional protein sources in livestock ration. The present work examines the effect of replacement of soybean meal with rice dried distillers grains with solubles in the concentrate mixtures at graded levels on in vitro nutrient digestibility, methane production and rumen fermentation parameters in buffalo inoculum.

\section{Materials and Methods}

\section{Sample collection and preparation}

Conventional concentrate mixture was prepared (maize 34, SBM 15, mustard cake15, wheat bran 10 , rice polish 6 , deoiled rice polish 17, mineral mixture 2 and salt 1 part). Soybean meal in the concentrate mixture was replaced by RDDGS at 0, 25, 50, 75 and $100 \%$ levels on $\mathrm{N}$ basis to formulate 5 concentrate mixtures.

\section{Proximate and cell wall constituents}

Concentrate mixtures were analyzed for dry matter (DM), Kjeldahl N, ether extract (EE) and ash content using the standard procedures (AOAC, 2000). Crude protein (CP) content of samples was determined as Kjeldahl $\mathrm{N} \times 6.25$ by digesting in sulphuric acid and digestion mixture (consisting of sodium/potassium sulphate and copper sulphate in 10:1 ratio) using semiauto-analyser (Kel Plus ClassicDX, Pelican). Cell wall fractions, viz. NDF, $\mathrm{ADF}$, cellulose and lignin were estimated sequentially using the standard procedure (Van Soest et al., 1991). NDF and ADF were expressed inclusive of residual ash. Lignin was determined by solublization of cellulose with72 per cent sulphuric acid. Acid detergent insoluble protein and neutral detergent insoluble protein were determined as per Licitra et al., (1996).

\section{In vitro evaluation}

The nutritional worth of various concentrates formulated was assessed by in vitro gas production technique (Menke et al., 1979; Menke and Steingass, 1988). Rumen fistulated male buffaloes maintained on $2 \mathrm{~kg}$ conventional concentrate mixture (maize 20, wheat 15 , deoiled mustard cake 10 , mustard cake 10 , soybean meal 15 , rice bran 15 , deoiled rice bran 12, mineral mixture 2, common salt 1part), $5 \mathrm{~kg}$ green and ad lib wheat straw were used as a donor for rumen liquor. Two sets of samples were incubated in triplicates. In the $\mathrm{I}^{\text {st }}$ set, about $375 \mathrm{mg}$ of the ground sample (dry matter basis) was incubated at $39^{\circ} \mathrm{C}$ for $24 \mathrm{~h}$ in triplicate in 100 $\mathrm{ml}$ calibrated glass syringes with buffered rumen fluid for assessing the net gas production, digestibility of nutrients and metabolizable energy (ME) availability. Individual volatile fatty acids were determined by using GLC equipped with a glass column (6 ft length and 1/8 inch diameter) packed with chromosorb 101. Samples were prepared by adding $0.2 \mathrm{ml}$ of $25 \%$ metaphosphoric acid per $\mathrm{ml}$ of rumen liquor, allowing it to stand for $2 \mathrm{~h}$ followed by centrifugation at $4000 \mathrm{rpm}$ for 7 min. Supernatant was used for estimation of individual volatile fatty acids (IVFA).

In the $2^{\text {nd }}$ set, total gas production was recorded after $24 \mathrm{~h}$ of incubation. From the headspace of each syringe, $100 \mu \mathrm{l}$ gas was 
collected by puncturing the silicon tube and injected in gas chromatograph for the estimation of methane. Standard calibration gas (Sigma gases, New Delhi) consisted of equal proportion of methane and carbon dioxide.

The flow rates for nitrogen, hydrogen and zero air were 30, 30, $320 \mathrm{ml} / \mathrm{min}$ respectively. Blank and standard hay (berseem hay) were run in triplicate with each set.

\section{Statistical analysis}

The data were subjected to one-way analysis of variance procedure using SPSS (2012), using the linear model. The post-hoc comparison of means was done for the significant difference by Tukey's b. Significant differences of treatments were considered at $\mathrm{P}<0.05$ level.

\section{Results and Discussion}

Chemical composition of concentrate mixtures with graded levels of RDDGS, \% DM basis

The CP of concentrate mixture 1 (control)and concentrate mixtures with graded levels of RDDGS varied from $21.53 \%$ to $22.21 \%$ (Table 2). All the concentrate mixtures formulated were iso-nitrogenous.

The ether extract content of concentrate mixtures varied between $4.73 \%$ and $5.08 \%$ and increased slightly with increase in the inclusion of RDDGS replacing SBM. The NDF content in concentrate mixtures varied from $30.13 \%$ to $35.33 \%$. The total carbohydrates (TCHO) in concentrate mixture 1 (control) was 65\% while in RDDGS containing concentrate mixtures, it varied from 64.85 to $65.61 \%$. The ADICP and NDICP in concentrates increased with increase in the level of RDDGS in the ration.
In vitro evaluation of concentrate mixture containing graded levels of RRDGS

\section{Net gas production}

The inclusion of graded levels of RDDGS in the concentrate mixtures didn't show any significant effect on the net gas production (Table 3). The NGP ranged from 207.83 to $222.08 \mathrm{ml} / \mathrm{g} \mathrm{DM} / 24 \mathrm{~h}$. The results in the present study are in agreement with the studies of Segers et al., (2014) which revealed no effect of DDGS supplementation on NGP. However, present results of NGP were not in agreement with Yogi et al., (2017) where the NGP decreased $(\mathrm{P}<0.01)$ with incremental levels of RDDGS replacing oil seed cakes as well as with Pecka Kielb et al., (2015) where the total gas production increased $(\mathrm{P}<0.01)$ with inclusion of corn DDGS in diet.

Truly degraded substrate (TDS) (mg) of the concentrate mixtures didn't differ significantly with inclusion of graded levels of RDDGS in the concentrate mixtures (Table 3). The TDS (mg) of concentrate mixtures ranged between 346.82 and 347.21.The inclusion of graded levels of RDDGS in concentrate mixtures didn't show any significant effect on partitioning factor $(\mathrm{PF})$ in the concentrate mixtures. The PF of concentrate mixtures ranged from 3.61 to 3.84 . The $\mathrm{PF}$ is the ratio of organic matter degraded (mg) in vitro to the volume of gas $(\mathrm{ml})$ produced. A higher partitioning factor means that proportionally more of the degraded matter is incorporated into microbial mass i.e. the efficiency of microbial protein synthesis is higher. The partitioning factor calculated in vitro provides useful information for predicting the dry matter intake, microbial mass production in the rumen and the methane emission of the ruminant animal. The PF of ruminant diets should be in the range of 2.71-4.41 (Blummel et al., 1997). The PF in the present study ranged between 3.61 and 3.84 which is within the suggested range. 


\section{Nutrient digestibility}

The OM digestibility was higher $(\mathrm{P}<0.05)$ in concentrate mixture 3 (50\% RDDGS) (87.61\%) than concentrate mixture 1 (control) and concentrate mixture 2 (25\% RDDGS) and it was statistically similar to that in concentrate mixture $4 \quad(75 \%$ RDDGS $)$ $(86.47 \%)$ and concentrate mixture $5(100 \%$ RDDGS) (86.46\%) (Table 3). The neutral detergent fiber digestibility (NDFD \%) was lower $(\mathrm{P}<0.05)$ in concentrate mixture 1 (control)(48.20\%)and concentrate mixture 2 (25\% RDDGS) (48.42\%) as compared to other concentrate mixtures. The digestibility of DM, $\mathrm{NDF}$ and $\mathrm{OM}$ of the concentrates containing $50 \%, 75 \%$ and $100 \%$ RDDGS levels replacing SBM was higher $(\mathrm{P}<0.05)$ than concentrate mixture 1 (control) in the present study. However, Geron et al., (2017) reported no effect of inclusion of DDGS on IVDMD and IVOMD. Contrarily, Yogi et al (2017) showed that IVDMD decreased $(\mathrm{P}<0.01)$ after $50 \%$ inclusion of RDDGS replacing oil cakes, whereas IVOMD was unaffected except at $100 \%$ RDDGS where it was reduced.

The microbial mass production (MMP, mg) of concentrate mixtures ranged between 112.37 and 127.95 (Table 3). The MMP of concentrate mixtures with graded levels of RDDGS increased $(\mathrm{P}>0.05)$ non significantly with increasing concentrations of RDDGS replacing SBM. However, Yogi et al (2017) reported a significant increase $(\mathrm{P}<0.01)$ in the MBP with the inclusion of RDDGS replacing oil seed cakes in the diets. The inclusion of graded levels of RDDGS in concentrate mixtures didn't show any significant effect on efficiency of microbial mass production (EMMP) in the concentrate mixtures. The EMMP of concentrate mixtures ranged from 39.04 to $42.63 \%$ which increased with increasing levels of RDDGS in concentrate mixtures replacing SBM numerically, however, the increase was statistically nonsignificant.
The inclusion of graded levels of RDDGS in concentrate mixtures didn't show any significant effect on short chain fatty acid production (SCFA) in the concentrate mixtures (Table 3). The SCFA (mmole) ranged between 0.92 and 0.93 among the concentrate mixtures evaluated. The availability of metabolisable energy (ME, $\mathrm{MJ} / \mathrm{kg} \mathrm{DM})$ was lower $(\mathrm{P}<0.05)$ in concentrate mixture 2 (25\% RDDGS) (9.79) and concentrate mixture 1 (control) (9.82) (Table $3)$. The ME was higher $(\mathrm{P}<0.05)$ in concentrate mixture 3 (50\% RDDGS) (10.33) as compared to concentrate mixture 1 (control). Beyond 75\% RDDGS inclusion replacing SBM, the ME decreased $(\mathrm{P}<0.05)$ in concentrate mixture 5 (100\% RDDGS) (9.80), however, it was statistically similar to that in concentrate mixture 1 (control) and concentrate mixture 2 (25\% RDDGS). The ME availability was highest $(\mathrm{P}<0.05)$ in concentrate 3 and 4 containing 50 and $75 \%$ RDDGS, respectively replacing SBM.

The ammonical-N of the concentrate mixtures decreased $(\mathrm{P}<0.05)$ with the increase in the inclusion of graded levels of RDDGS in concentrate mixtures replacing SBM (Table 3). The ammonical-N (mg/dl) was highest $(\mathrm{P}<0.05)$ in concentrate mixture 1 (control) $(30.38 \mathrm{mg} / \mathrm{dl})$ and in concentrate mixture 2 (25\% RDDGS) $(28.78 \mathrm{mg} / \mathrm{dl})$ as compared to other concentrate mixtures. The ammonical-N in concentrate mixture 3 (50\% RDDGS) $(25.67 \mathrm{mg} / \mathrm{dl})$ was higher $(\mathrm{P}<0.05)$ than concentrate mixture 4 (75\% RDDGS) (23.56 $\mathrm{mg} / \mathrm{dl}$ ) followed by that in concentrate mixture 5 (100\% RDDGS) (22.16mg/dl). Ruminal ammonia-N $\left(\mathrm{NH}_{3}-\mathrm{N}\right)$, which is the main source of $\mathrm{N}$ for microbial protein synthesis, results from microbial degradation of rumen degradable protein (RDP) (Reed et al., 2006). The results are in accordance with the results obtained by Walter et al., (2012) and Yogi et al.,(2017) where the $\mathrm{NH}_{3}-\mathrm{N}$ decreased $(\mathrm{P}<0.01)$ with inclusion of DDGS in the diets. This might be due to the higher rumen 
undegradable protein in RDDGS which resulted in lower proteolytic activity in rumen leading to lower ammonia production.

\section{Individual VFA production}

The TVFA production decreased $(\mathrm{P}<0.05)$ with increasing level of RDDGS in the concentrate mixtures (Table 4). The TVFA $(\mathrm{mM} / \mathrm{dl})$ production was highest $(\mathrm{P}<0.05)$ in concentrate mixture 1 (control) (6.73) as compared to the concentrate mixtures containing graded levels of RDDGS. The TVFA production in concentrate mixture 2 (25\% RDDGS) (6.04) was higher $(\mathrm{P}<0.05)$ as compared to the concentrate mixtures containing 50\%, $75 \%$ and $100 \%$ RDDGS replacing SBM. The results in the present study are in agreement with results observed by Walter et al.,(2012) where the TVFA concentration decreased $(\mathrm{P}=0.03)$ linearly with the inclusion of wheat DDGS. The results obtained are also in agreement with Mista et al., (2014) and with Yogi et al., (2017) where the TVFA concentration decreased $(\mathrm{P}<0.05)$ with incremental levels of corn DDGS and RDDGS, respectively in the rations.

The acetic acid content $(\mathrm{mM} / \mathrm{dl})$ of the concentrate mixtures followed the same trend as TVFA and decreased $(\mathrm{P}<0.05)$ with increasing level of RDDGS replacing SBM in the concentrate mixtures (Table 4). The acetic acid $(\mathrm{mM} / \mathrm{dl})$ content was highest $(\mathrm{P}<0.05)$ in concentrate mixture 1 (control) $(3.96 \mathrm{mM} / \mathrm{dl})$ followed by concentrate mixture 2 (25\% RDDGS) (3.50), concentrate mixture 3 (50\% RDDGS) (3.28), concentrate mixture 4 (75\% DDGS) (3.09) and lowest $(\mathrm{P}<0.05)$ in concentrate mixture 5 (100\% RDDGS) (2.98). In the present study, the acetic acid concentration reduced with inclusion of RDDGS. Our results are in accordance with the results obtained by Yogi et al., (2017) whereas the results obtained by Walter $e t$ al (2012) and Mista et al., (2014) have showed no significant effect on acetic acid concentration where the grains were replaced by wheat DDGS and corn DDGS, respectively.

Table.1 Ingredient composition of concentrate mixtures (parts/100 parts)

\begin{tabular}{|l|c|c|c|c|c|}
\hline Ingredient & $\begin{array}{c}\text { CONC 1 } \\
\text { (Control) }\end{array}$ & $\begin{array}{c}\text { CONC 2 } \\
(25 \% \text { RDDGS })\end{array}$ & $\begin{array}{c}\text { CONC 3 } \\
\text { (50\%RDDGS })\end{array}$ & $\begin{array}{c}\text { CONC 4 } \\
\text { (75\% DDGS })\end{array}$ & $\begin{array}{c}\text { CONC 5 } \\
\text { (100\% RDDGS })\end{array}$ \\
\hline Maize & 34 & 34 & 34 & 34 & 34 \\
\hline SBM & 15 & 11.25 & 7.5 & 3.75 & 0 \\
\hline DDGS & 0 & 3.75 & 7.5 & 11.25 & 15 \\
\hline Mustard Cake & 15 & 15 & 15 & 15 & 15 \\
\hline Wheat Bran & 10 & 10 & 10 & 10 & 10 \\
\hline Rice Polish & 6 & 6 & 6 & 6 & 6 \\
\hline DORP & 17 & 17 & 17 & 17 & 17 \\
\hline Mineral Mixture & 2 & 2 & 2 & 2 & 2 \\
\hline Common Salt & 1 & 1 & 1 & 1 & 1 \\
\hline
\end{tabular}


Table. 2 Chemical composition of concentrate mixtures with graded levels of RDDGS, \% DM basis

\begin{tabular}{|l|l|l|l|l|l|}
\hline Parameters & CONC 1 & CONC 2 & CONC 3 & CONC 4 & CONC 5 \\
\hline OM & 91.75 & 91.88 & 92.32 & 92.22 & 92.18 \\
\hline CP & 22.01 & 22.19 & 22.21 & 22.03 & 21.53 \\
\hline EE & 4.73 & 4.84 & 5.08 & 5.01 & 5.04 \\
\hline Total ash & 8.25 & 8.12 & 7.68 & 7.78 & 7.82 \\
\hline NDF & 30.13 & 31.33 & 31.67 & 33.73 & 35.33 \\
\hline ADF & 13.27 & 12.17 & 13.53 & 12.77 & 14.67 \\
\hline Hemicellulose & 16.87 & 19.17 & 18.13 & 20.97 & 20.67 \\
\hline ADL & 4.23 & 4.40 & 4.30 & 4.60 & 4.77 \\
\hline TCHO & 65.00 & 64.85 & 65.03 & 65.17 & 65.61 \\
\hline ADICP & 4.96 & 5.84 & 7.18 & 8.88 & 8.50 \\
\hline NDICP & 9.18 & 11.91 & 14.55 & 16.08 & 16.13 \\
\hline
\end{tabular}

OM-organic matter, $\mathrm{CP}$ - crude protein, EE- ether extract, NDF- neutral detergent fibre, ADF- acid detergent fibre, ADL- acid detergent lignin, TCHO- total carbohydrates, ADICP- acid detergent insoluble crude protein, NDICPNeutral detergent insoluble crude protein.

Table.3 In vitro utilization of nutrients in concentrate mixtures containing graded levels of RDDGS (24h)

\begin{tabular}{|l|l|l|l|l|l|l|}
\hline Parameters & CONC 1 & CONC 2 & CONC 3 & CONC 4 & CONC 5 & SEM \\
\hline NGP, ml/g/ 24h & 210.98 & 207.95 & 222.08 & 217.13 & 207.83 & 2.07 \\
\hline TDS, mg & 346.82 & 346.88 & 347.12 & 347.21 & 347.10 & 0.30 \\
\hline PF, mg/ml & 3.61 & 3.64 & 3.64 & 3.67 & 3.84 & 0.13 \\
\hline OMD, \% & $82.99^{\mathrm{a}}$ & $83.42^{\mathrm{a}}$ & $87.61^{\mathrm{b}}$ & $86.47^{\mathrm{b}}$ & $86.46^{\mathrm{b}}$ & 0.71 \\
\hline NDFD, \% & $48.20^{\mathrm{a}}$ & $48.42^{\mathrm{a}}$ & $63.88^{\mathrm{b}}$ & $63.00^{\mathrm{b}}$ & $64.67^{\mathrm{b}}$ & 2.58 \\
\hline MMP, mg & 112.37 & 113.19 & 120.43 & 120.36 & 127.95 & 2.19 \\
\hline EMMP, \% & 39.04 & 39.59 & 39.60 & 40.09 & 42.63 & 0.53 \\
\hline DMD, \% & $84.39^{\mathrm{a}}$ & $83.84^{\mathrm{a}}$ & $88.56^{\mathrm{b}}$ & $87.5^{\mathrm{b}}$ & $87.52^{\mathrm{b}}$ & 0.65 \\
\hline SCFA, mmole & 0.93 & $0.92^{\mathrm{a}}$ & 0.98 & 0.96 & 0.92 & 0.01 \\
\hline $\mathbf{M E}^{\mathrm{a}} \mathbf{M J} \mathbf{\text { kg DM }}$ & $9.82^{\mathrm{a}}$ & $9.79^{\mathrm{a}}$ & $10.33^{\mathrm{b}}$ & $10.12^{\mathrm{ab}}$ & $9.80^{\mathrm{a}}$ & 0.08 \\
\hline NH3-N, mg/dl & $30.38^{\mathrm{c}}$ & $28.78^{\mathrm{c}}$ & $25.67^{\mathrm{b}}$ & $23.56^{\mathrm{a}}$ & $22.16^{\mathrm{a}}$ & 1.04 \\
\hline
\end{tabular}

NGP- Net gas production, TDS-truly degraded substrate, PF- partition factor, D- digestibility, OM- organic matter, NDF- neutral detergent fibre, MMP- microbial mass production, EMMP- efficiency of microbial mass production, DM-dry matter, SCFA- short chain fatty acids, ME- metabolizable energy $\mathrm{NH}_{3}-\mathrm{N}$-ammonical nitrogen, Means bearing different superscripts in a row differ significantly $(\mathrm{P}<0.05)$ 
Table.4 In vitro volatile fatty acids production (mM/dl) in concentrate mixtures containing graded levels of RDDGS

\begin{tabular}{|l|l|l|l|l|l|l|}
\hline Parameters & CONC 1 & CONC 2 & CONC 3 & CONC 4 & CONC 5 & SEM \\
\hline Acetate & $3.96^{\mathrm{e}}$ & $3.50^{\mathrm{d}}$ & $3.28^{\mathrm{c}}$ & $3.09^{\mathrm{b}}$ & $2.98^{\mathrm{a}}$ & 0.12 \\
\hline Propionate & $1.97^{\mathrm{c}}$ & $1.85^{\mathrm{b}}$ & $1.74^{\mathrm{a}}$ & $1.74^{\mathrm{a}}$ & $1.68^{\mathrm{a}}$ & 0.03 \\
\hline Isobutyrate & $0.074^{\mathrm{c}}$ & $0.068^{\mathrm{bc}}$ & $0.068^{\mathrm{bc}}$ & $0.060^{\mathrm{a}}$ & $0.065^{\mathrm{ab}}$ & 0.002 \\
\hline Butyrate & $0.31^{\mathrm{b}}$ & $0.29^{\mathrm{b}}$ & $0.27^{\mathrm{ab}}$ & $0.24^{\mathrm{a}}$ & $0.28^{\mathrm{ab}}$ & 0.01 \\
\hline Isovalerate & $0.286^{\mathrm{c}}$ & $0.228^{\mathrm{b}}$ & $0.213^{\mathrm{ab}}$ & $0.238^{\mathrm{b}}$ & $0.179^{\mathrm{a}}$ & 0.012 \\
\hline Valerate & $0.12^{\mathrm{d}}$ & $0.11^{\mathrm{c}}$ & $0.10^{\mathrm{b}}$ & $0.08^{\mathrm{a}}$ & $0.08^{\mathrm{a}}$ & 0.01 \\
\hline TVFA & $6.73^{\mathrm{e}}$ & $6.04^{\mathrm{d}}$ & $5.67^{\mathrm{c}}$ & $5.44^{\mathrm{b}}$ & $5.26^{\mathrm{a}}$ & 0.17 \\
\hline A:P & $2.01^{\mathrm{c}}$ & $1.89^{\mathrm{b}}$ & $1.89^{\mathrm{b}}$ & $1.78^{\mathrm{a}}$ & $1.77^{\mathrm{a}}$ & 0.03 \\
\hline Relative proportion, \% & & & & & \\
\hline Acetate & $58.87^{\mathrm{c}}$ & $57.89^{\mathrm{b}}$ & $57.90^{\mathrm{b}}$ & $56.79^{\mathrm{a}}$ & $56.57^{\mathrm{a}}$ & 0.28 \\
\hline Propionate & $29.30^{\mathrm{a}}$ & $30.60^{\mathrm{b}}$ & $30.70^{\mathrm{b}}$ & $31.92^{\mathrm{c}}$ & $32.02^{\mathrm{c}}$ & 0.34 \\
\hline Isobutyrate & $1.10^{\mathrm{a}}$ & $1.12^{\mathrm{a}}$ & $1.20^{\mathrm{ab}}$ & $1.11^{\mathrm{a}}$ & $1.23^{\mathrm{b}}$ & 0.02 \\
\hline Butyrate & 4.66 & 4.80 & 4.73 & 4.39 & 5.29 & 0.11 \\
\hline Isovalerate & $4.25^{\mathrm{b}}$ & $3.77^{\mathrm{ab}}$ & $3.76^{\mathrm{ab}}$ & $4.37^{\mathrm{b}}$ & $3.40^{\mathrm{a}}$ & 0.13 \\
\hline Valerate & $1.82^{\mathrm{b}}$ & $1.81^{\mathrm{b}}$ & $1.70^{\mathrm{b}}$ & $1.42^{\mathrm{a}}$ & $1.49^{\mathrm{a}}$ & 0.06 \\
\hline
\end{tabular}

TVFA-Total volatile fatty acids, A:P- acetate:propionate, Means bearing different superscript in a row differ significantly $(\mathrm{P}<0.05)$

Table.5 Methane production from fermentation of concentrate mixtures containing graded levels of RDDGS (24 h)

\begin{tabular}{|l|l|l|l|l|l|l|}
\hline Parameters & CONC 1 & CONC 2 & CONC 3 & CONC 4 & CONC 5 & SEM \\
\hline CH $_{4}, \mathbf{m l}$ & 5.51 & 6.39 & 6.78 & 5.72 & 5.64 & 0.19 \\
\hline $\mathbf{C H}_{4}, \mathbf{m l} / \mathbf{g}$ DM & 27.54 & 31.91 & 33.88 & 28.62 & 28.19 & 0.95 \\
\hline $\mathbf{C H}_{4}, \mathbf{m l} / \mathbf{1 0 0 m g}$ DMD & 3.31 & 3.83 & 3.85 & 3.31 & 3.27 & 0.11 \\
\hline $\mathbf{C H}_{4}, \mathbf{m l} / \mathbf{1 0 0 m g}$ OMD & 3.67 & 4.23 & 4.22 & 3.64 & 3.59 & 0.12 \\
\hline
\end{tabular}

Table.6 Hydrogen balance of concentrate mixtures containing graded levels of RDDGS (24h)

\begin{tabular}{|l|l|l|l|l|l|l|}
\hline Parameters & CONC 1 & CONC 2 & CONC 3 & CONC 4 & CONC 5 & SEM \\
\hline H-recovery, \% & $91.33^{\mathrm{a}}$ & $97.88^{\mathrm{b}}$ & $101.35^{\mathrm{c}}$ & $103.36^{\mathrm{c}}$ & $107.88^{\mathrm{d}}$ & 1.87 \\
\hline H-consumed via CH4 & $6.16^{\mathrm{d}}$ & $5.68^{\mathrm{c}}$ & $5.32^{\mathrm{b}}$ & $5.00^{\mathrm{a}}$ & $5.20 \mathrm{a}^{\mathrm{b}}$ & 0.14 \\
\hline FE, \% & $77.83^{\mathrm{a}}$ & $78.41^{\mathrm{b}}$ & $78.44^{\mathrm{b}}$ & $79.01^{\mathrm{c}}$ & $79.06^{\mathrm{c}}$ & 0.15 \\
\hline VFA UI & $2.25^{\mathrm{c}}$ & $2.14^{\mathrm{b}}$ & $2.13^{\mathrm{b}}$ & $2.01^{\mathrm{a}}$ & $2.05^{\mathrm{ab}}$ & 0.03 \\
\hline
\end{tabular}

H- Hydrogen, FE- Fermentation efficiency, VFA UI- volatile fatty acids utilization index, Means bearing different superscripts in a row differ significantly $(\mathrm{P}<0.05)$ 
The propionic acid content $(\mathrm{mM} / \mathrm{dl})$ was higher $(\mathrm{P}<0.05)$ in concentrate mixture 1 (control) (1.97) as compared to the other concentrate mixtures (Table 4). The propionic acid content of concentrate mixture $2(25 \%$ RDDGS) (1.85) was higher $(\mathrm{P}<0.05)$ than concentrate mixtures 3,4 and 5 containing $50 \%, 75 \%$ and $100 \%$ RDDGS levels, respectively. The relative proportion of propionic acid was higher $(\mathrm{P}<0.05)$ in concentrate mixture 4 (75\% RDDGS) and concentrate mixture 5 (100\% RDDGS) than concentrate mixture 1 (control), concentrate mixture 2 (25\% RDDGS) and concentrate mixture 3 (50\% RDDGS).

The A: $\mathrm{P}$ ratio of concentrate mixture 1 (control) (2.01) was higher $(\mathrm{P}<0.05)$ as compared to other concentrate mixtures (Table 4). The A: $\mathrm{P}$ ratio of concentrate mixture 2 (25\% DDGS) and concentrate mixture 3 (50\% RDDGS) was higher $(\mathrm{P}<0.05)$ than concentrate mixture $4 \quad(75 \%$ RDDGS) (1.78) and concentrate mixture 5 (100\% RDDGS) (1.77). The propionic acid content was lower $(\mathrm{P}<0.05)$ in the diets containing different levels of RDDGS whereas the relative proportion of propionate has increased $(\mathrm{P}<0.05)$ with the increase in the inclusion level of RDDGS and subsequently the A: $\mathrm{P}$ ratio decreased $(\mathrm{P}<0.05)$ with the RDDGS inclusion in the ration. The results obtained in the present study are in agreement with the results obtained by Yogi et al., (2017) where oil cakes were replaced by graded levels of RDDGS.

The isobutyrate content decreased $(\mathrm{P}<0.05)$ with increasing level of RDDGS in the concentrate mixtures (Table 4).

\section{References}

AOAC, 2000. Official Methods of Analysis. 17 th ed. Association of official
Analytical Chemists, Washington DC. Blummel, M., Makkar, H.P.S and Becke, K. 1997. In vitro gas production: a technique revisited. J. Anim. Physio and Anim.Nutr.,77: 24-34.

Geron, J.V., Garcia, J., Martins Coelho, K.S., Sílvia Cristina de guiar, Moura Zanine, A, de Souza, A.L., Carvalho, J.T.H, Roberto, L.S., Neto, E. L. S. and Ferreira, D.J.2017. In vitro digestibility and nutritional characterization of distillers dried grains with solubles according to the Cornell Net Carbohydrate and Protein System. Ciências Agrárias Londrina., 38(4): 2029-40.

Licitra, G., Hernandez, T.M. and Van Soest, P.J. 1996. Standardisation of procedures for nitrogen fractionation of ruminant feeds. Anim Feed Sci and Tech.,57: 347-30058.

Menke, K.H., Raab, L., Salewski, A., Steingass, H., Fritz, D. and Scheinder, W. 1979. The estimation of the digestibility and metabolizable energy content of ruminant feed stuffs from the gas production when they are incubated with rumen liquor in vitro. J. Agric. Sci. Camb.,92: 217-222.

Menke, K.H. and Steingass, H. 1988. Estimation of the energetic feed value obtained from chemical analysis and in vitro gas production using rumen fluid. Anim. Res. Dev., 28:7-55

Mista, D., Pecka, E., Zachwieja, A., Zawadzki, W.,Bodarski, R., Paczynska, K., Tumanowicz, J., Kupczynski, R. and Adamski, M.2014. In Vitro Ruminal Fluid Fermentation as Influenced by CornDerived Dried Distillers Grains with Solubles. Folia Biologica (Kraków)., 62: 345-51.

NationalLivestockcensus, 2012.19 ${ }^{\text {th }}$ Livestock census. All India report. Ministry of Agriculture, Department of Animal 
Husbandry, Dairying and Fisheries, Krishi Bhawan,NewDelhi.

Pecka-Kielb E., Zawadzki, W., Zachwieja, A., Michel, O., Mazur, M. and Mista, D.2015. In vitro study of the effect of corn dried distillers grains with solubles on rumen fermentation in sheep. Polish J. Vet. Sci., 18(4): 75158.

Reed, J.J., Lardy, G.P., Bauer, M.L., Gibson, M., and Caton, J.S. 2006. Effects of season and inclusion of corn distillers dried grains with solubles in creep feed on intake, microbial protein synthesis and efficiency, ruminal fermentation, digestion, and performance of nursing calves grazing native range in southeastern North Dakota. J. Anim. Sci., 84:2200-12.

Segers,J.R., Stelzleni, A.M., Pringle, T.D., Froetschel, M.A., Ross, C.L. and Stewart, R.L. 2014. Use of corn gluten feed and dried distillers grains plus solubles as a replacement for soybean meal and corn for supplementation in a corn silage-based stocker system.J. Anim. Sci., 91:950-56.

SPSS,2012. Statistical Packages for Social Sciences (version 21.0) SPSS Inc. Chicago, IL, USA.

Van Soest, P. J., Robertson, J. B. and Lewis, B. A. 1991. Methods for dietary fiber, neutral detergent fiber and non starch polysaccharides in relation to animal nutrition. J. Dairy Sci., 74: 3583-3597.

Walter, L.J., McAllister, T.A., Yang, W.Z., Beauchemin, K.A., He, M. and McKinnon, J. J. 2012. Comparison of wheat or corn dried distillers grains with solubles on rumen fermentation and nutrient digestibility by feedlot heifers. J. Anim., Sci. 90:1291-1300.

Yogi, R. K., Thakur, S.S., Madhu, M., Singh, S.K. and Tariq, M. 2017. In Vitro evaluation of concentrate mixtures containing incremental level of rice dried distillers grain with solubles replacing oil cakes in concentrate mixture. Indian J. Anim. Nutr.,34 (2): 163-168.

\section{How to cite this article:}

Chandrika, R.N., Jasmine Kaur, J.S. Lamba and Grewal, R.S. 2018. In vitro Nutrient Digestibility and Fermentation Pattern of Concentrate Mixtures Containing Incremental Levels of Dried Distillers Grains with Solubles. Int.J.Curr.Microbiol.App.Sci. 7(07): 1774-1782. doi: https://doi.org/10.20546/ijcmas.2018.707.210 